Summer 2019

\title{
"Enimies to Mankind": Convict Servitude, Authority, and Humanitarianism in the British Atlantic World
}

Nicole K. Dressler

nkdressler@wm.edu

Follow this and additional works at: https://scholarworks.wm.edu/aspubs

Part of the European History Commons, and the United States History Commons

\section{Recommended Citation}

Dressler, Nicole K., "Enimies to Mankind": Convict Servitude, Authority, and Humanitarianism in the British Atlantic World (2019). Early American Studies: An Interdisciplinary Journal.

https://scholarworks.wm.edu/aspubs/1819

This Article is brought to you for free and open access by the Arts and Sciences at W\&M ScholarWorks. It has been accepted for inclusion in Arts \& Sciences Articles by an authorized administrator of W\&M ScholarWorks. For more information, please contact scholarworks@wm.edu. 


\section{YEARS}

\section{PROJECT MUSE}

"Enimies to Mankind": Convict Servitude, Authority, and

Humanitarianism in the British Atlantic World

Nicole K. Dressler

Early American Studies: An Interdisciplinary Journal, Volume 17, Number 3, Summer 2019, pp. 343-376 (Article)

Published by University of Pennsylvania Press

DOI: https://doi.org/10.1353/eam.2019.0010

$\Rightarrow$ For additional information about this article https://muse.jhu.edu/article/729713 


\title{
"Enimies to Mankind"
}

\section{Convict Servitude, Authority, and Humanitarianism in the British Atlantic World}

\author{
NICOLE K. DRESSLER \\ College of William and Mary
}

\begin{abstract}
This study examines the role that British convict transportation and penal servitude in America played in the early history of humanitarianism. During the eighteenth century Britons' and Americans' ideas about moral obligations and suffering changed drastically toward traditionally detested people, including transported convicts, enslaved Africans, sailors, and the poor. Historians have made it clear that people in the eighteenth century created unprecedented ways to understand the human condition, and studying coerced labor of all kinds tells scholars more about how unfreedom shaped the language, ethics, and practices of the early stages of humanitarianism. In the eighteenth century British courts banished over 50,000 convicted men, women, and children to the American colonies, many of whom were sold as convict servants. This study argues that emerging ideas of punishment, morality, and unfreedom evoked by convict labor created new moral responsibilities, widened the plane of sympathies, and inspired novel denunciations of suffering in eighteenth century Anglo-American culture. Institutional banishment and convict servitude had unintentional consequences for both Britain and America, and moralists and elites constructed a new discursive environment that raised complex questions and generated new debates about labor, coercion, and cruelty in the Age of Enlightenment and Revolution.
\end{abstract}

I wish to thank the anonymous readers at Early American Studies for their valuable suggestions and Roderick McDonald, the journal's editor, for his assistance and expertise. Earlier versions of the article were presented at the American Historical Association, Northern Illinois University, and the English Atlantic Writing Group of Loyola University Chicago. The panelists, audience members, and colleagues provided critical and greatly appreciated feedback. I am deeply grateful to Aaron Fogleman, Sean Farrell, Heide Fehrenbach, and Jim Schmidt, who offered insightful comments on multiple drafts. Generous financial support for this article was given by the McNeil Center for Early American Studies, Library Company of Philadelphia, the American Philosophical Society, and the Global Humanitarianism Research Academy. 
In the summer of 1735, Edward Williams snuck away with sheepskins and buckskins from his master's shop in Colebrook, England. With the skins concealed in two bundles, he convinced one homeowner to let him spend the night when he claimed "there were so many wicked Houses about Town." Later that evening, Williams had a pint of beer and began talking, perhaps flirting with the homeowner's maid, apparently being "very rude to her." The maid and the homeowner became suspicious, and they peered into his guarded bundles lying on the other side of the bar. They found the skins and, suspecting he was a thief, they quickly called the constable to take him away. In September at the Old Bailey courthouse in London, witnesses stacked their evidence against Williams's alibi, convincing the jury that he was, indeed, a devious thief. Williams must have realized the odds were against him and that he would probably be transported to the American colonies as punishment. He begged the court, "I hope for Mercy in the Kingdom of Heaven. But for Christ's Sake! for the Lord Jesus Sake! let me have my Punishment in my own Country." ${ }^{1}$

Edward Williams's statement captures the distress of being transported abroad, but it also reveals Britons' and Americans' heightened concerns about temporary bondage and severe punishments, as well as changing moral sensibilities across the Anglo-American world. During the eighteenth century ideas about moral obligations and suffering changed drastically toward traditionally detested people, including convicts, enslaved Africans, sailors, and the poor. Historians, including Thomas Laqueur and Lynn Hunt, have shown how eighteenth-century people created new ways to understand the human condition. Although many histories of humanitarianism and human rights underestimated its early modern roots, scholars have recently challenged the monolithic "textbook narrative of origins" on human rights cultures and launched new investigations into the historical foundations of the movement. ${ }^{2}$ These studies have focused on evangelical

1. Trial of Edward Williams, September 11, 1735, Old Bailey Proceedings Online, www.oldbaileyonline.org, t17350911-50.

2. Karen Halttunen, "Humanitarianism and the Pornography of Pain in AngloAmerican Culture," American Historical Review 100, no. 2 (1995): 303-4; Elizabeth B. Clark, "'The Sacred Rights of the Weak': Pain, Sympathy, and the Culture of Individual Rights in Antebellum America," Journal of American History 82, no. 2 (1995): 463; Richard Ashby Wilson and Richard D. Brown, introduction to Wilson and Brown, eds., Humanitarianism and Suffering: The Mobilization of Empathy (Cambridge: Cambridge University Press, 2009), 9-11; Miia Halme-Tuomisaari and Pamela Slotte, "Revisiting the Origins of Human Rights: Introduction," in Slotte and Halme-Tuomisaari, eds., Revisiting the Origins of Human Rights (Cambridge: Cambridge University Press, 2015), 1; Abigail Green, "Humanitarianism in 
philanthropy and antislavery, the latter often serving as the starting point for historical investigations into the movement. Historians are right to stress the importance of abolitionist writings in the history of humanitarianism, showing how events as seemingly disparate as long-distance markets and revolutions wrought antislavery sentiment and new sensibilities. As scholars have recently pointed out, however, humanitarianism did not emerge solely from the antislavery campaign. An examination of coerced labor, such as convict servitude- the punishment that our thief, Edward Williams, faced-offers a broader narrative that reveals important ways that complex social, cultural, and economic developments gave rise to new understandings of pain, benevolence, and morality in the modern world. ${ }^{3}$

Nineteenth-Century Context: Religious, Gendered, National," Historical Journal 57, no. 4 (2014): 1157-58; For more on humanitarianism and human rights, see Thomas L. Haskell, "Capitalism and the Origins of the Humanitarian Sensibility, Part 1 and Part 2," American Historical Review 90, nos. 2 and 3 (1985): 339-61 and 547-66; Lynn Avery Hunt, Inventing Human Rights: A History (New York: W. W. Norton, 2007); Michael N. Barnett, Empire of Humanity: A History of Humanitarianism (Ithaca: Cornell University Press, 2011); Lynn Festa, "Humanity without Feathers," Humanity: An International Journal of Human Rights, Humanitarianism, and Development 1, no. 1 (2010): 3-27; Thomas Laqueur, "Bodies, Details, and the Humanitarian Narrative," in Lynn Hunt, ed., The New Cultural History (Berkeley: University of California Press, 1989), 176-204. For a work reorienting the periodization of human rights histories, see Samuel Moyn, The Last Utopia: Human Rights in History (Cambridge: Belknap Press of Harvard University Press, 2010); Wilson and Brown define humanitarianism as "the wish to promote human welfare." Different from human rights endeavors, humanitarian efforts aim to alleviate suffering and aid other human beings. These efforts do not always operate in a defense of rights. See Wilson and Brown, Humanitarianism and Suffering, 11.

3. Haskell, "Capitalism and the Origins of the Humanitarian Sensibility, Part 1 and Part 2"; Christopher Leslie Brown, Moral Capital: Foundations of British Abolitionism (Chapel Hill: University of North Carolina Press, 2006); Amanda B. Moniz, From Empire to Humanity: The American Revolution and the Origins of Humanitarianism (Oxford: Oxford University Press, 2016), 3-6. Historiographical debates on the emergence of humanitarianism and human rights have explored the role of capitalism, print culture, redistribution of wealth, and slavery and abolitionism. Historians have dedicated extensive praise as well as critique to Eric Williams's 1944 work, Capitalism and Slavery, which sparked significant controversies over abolition's economic or humanitarian origins. Following significant challenges to the Williams thesis, most notably that of Seymour Drescher's 1977 work, Econocide, many scholars today still debate the economic or humanitarian initiatives concerning abolition. See Eric Williams, Capitalism and Slavery (Chapel Hill: University of North Carolina Press, 1944); David Brion Davis, The Problem of Slavery in Western Culture (Ithaca: Cornell University Press, 1966); Seymour Drescher, Econocide: British Slavery in the Era of Abolition (1977), 2nd ed. (Chapel Hill: University of North 
An examination of the history of the British convict trade and servitude in America shows how convict transportation shaped emerging discussions about humanity and expanded the sphere of human sympathy in AngloAmerican culture. In the eighteenth century, British courts banished over 50,000 convicted men, women, and children to the American colonies- the largest group of people forcibly removed from Europe to the Americas in the century - many of whom were sold as convict servants. Transportation added to the labor pool in the growing colonial project in North America and removed offenders from Britain's communities, yet inhabitants on both sides of the Atlantic spent years contesting the economic efficiency of the trade and evoked moral reasoning and responsibilities to defend their stance on banishment and servitude. In the early modern British Atlantic world, the majority of people who labored -including vagrants, criminals, enslaved people, and bound servants- did so in some form of dependency or unfreedom. Convict servitude was distinct from other forms of unfree labor and unequivocally different from the cruel and dehumanizing institution of African slavery, since the latter was racialized, inheritable, and perpetual. With these important distinctions, many unfree people endured similar material conditions and formed common bonds with one another. The historian Kenneth Morgan has noted that the responses to convict transportation showed "the emergence of a humanitarian conscience," but we need to know more about how these moral ideas concerning bound labor translated into discourse, influencing the early movement of humanitarianism. How did attitudes toward the convict trade evoke sensibilities and shift over the course of the century? In what ways did interlocutors use penal servitude to discuss and defend or oppose coerced labor systems, such as African chattel slavery? To what extent did it shape elite and moralist ideas about unfreedom and human responsibility? Institutional banishment and convict servitude had unintentional consequences for both Britain and America, and moralists and elites constructed a new discursive environment that raised complex questions and generated new debates about coerced labor, unfreedom, and cruelty in the Age of Enlightenment and Revolution. ${ }^{4}$

Carolina Press, 2010); Seymour Drescher, review of The Antislavery Debate: Capitalism and Abolitionism as a Problem in Historical Interpretation, ed. Thomas Bender, History and Theory 32, no. 3 (1993): 311-29; Brown, Moral Capital. For a more recent work refining Williams's thesis, see David Ryden, West Indian Slavery and British Abolition, 1783-1807 (Cambridge: Cambridge University Press, 2009).

4. Simon P. Newman, A New World of Labor: The Development of Plantation Slavery in the British Atlantic (Philadelphia: University of Pennsylvania Press, 2013), 2-3; Kenneth Morgan, "English and American Attitudes towards Convict Trans- 
Evidence drawn from British and American legal and court records, commentaries, and newspapers allows us to chart how penal servitude in the British Atlantic evoked new rhetoric and debates that, by the second half of the eighteenth century, connected with and influenced a broader discourse on coerced labor and human suffering. Like many humanitarian narratives, the discourse surrounding the convict trade does not convey a tidy monolithic strand of thinking about unfreedom: some Britons and Americans expressed disgust with convicts, while others argued that the punishment promoted offenders' moral growth. Anxieties about the temporary bondage of penal servitude went beyond offenders and judicial authorities; interlocutors used sentimental accounts to define offenders' humanity (or lack thereof) and to judge whether they deserved to suffer, labor, and even live. The moral articulations and actions concerning convict servitude reveal how labor systems played a critical role in influencing early modern moralists' and reformers' thinking and rhetoric, while shaping the early movement of humanitarianism in the Anglo-American world.

\section{SENSIBILITY AND THE EARLY OPERATIONS OF THE CONVICT TRADE}

For centuries, severe punishments and stark inequalities had categorized societies and hierarchies in Western culture, but by the eighteenth century writers, lawmakers, and moralists throughout the Atlantic world were breaking with these earlier traditions through their critiques of harsh punishments, brutal acts of torment, and various categories of unfreedom. Epistolary novels and sentimental narratives, for example, allowed readers to empathize with a sufferer's pain and imagine new ways to reduce misery. Shaped by John Locke's work on sensation and later investigations on the moral sense in human nature, the culture of sensibility expanded, prompting people to act benevolently toward those outside their own religious,

portation, 1718-1775," History 72, no. 236 (1987): 423; A. Roger Ekirch, Bound for America: The Transportation of British Convicts to the Colonies, 1718-1775 (Oxford: Clarendon Press, 1987), 142, 145-52; Nicole K. Dressler, "The 'Vile Commodity': Convict Servitude, Authority, and the Rise of Humanitarianism in the AngloAmerican World, 1718-1809" (Ph.D. diss., Northern Illinois University, 2018). Using a legal lens, Alan Atkinson stated that in the 1720s and until about the 1740s, colonists legally understood convicts as being similar to indentured servants; afterward, however, lawmakers passed acts to disassociate convicts from indentured servants. See Alan Atkinson, "The Free-Born Englishman Transported: Convict Rights as a Measure of Eighteenth-Century Empire," Past \& Present 144 (August 1994): 88-115. 
national, economic, racial, and ethnic groups. Sentimentality may have been a significant cornerstone in the early humanitarian movement, but sentimental sympathy operated selectively and unevenly, "exciting feelings about particularly moving examples of suffering and recognizing these subjects exclusively based on the fact of that suffering." According to Lynn Festa, the "sentimental process" showed readers how to decide who would be accepted "within the sentimental community" and the qualities that made them human and undeserving of suffering. ${ }^{5}$ The crimes of transported convicts and their subsequent legal banishment outside the metropole had excluded them from their home communities, and they lamented the bodily and emotional pains endured during their punishment. These convicts drew on their local attachments and asserted the value of human life to incite sympathy for their situations, while judicial administrators and other interlocutors fashioned moralist critiques to justify, modify, or disrupt punishment by transportation. The language used to show the moral rectitude (or lack thereof) in the punishment demonstrates the important tensions between legal exclusion and emerging notions of cultural inclusion.

Edward Williams, the thief who had stolen sheepskins and buckskins, found himself part of a disciplinary experiment - convict transportationdesigned to alleviate a widely perceived crime problem in Britain. The British Parliament passed the Transportation Act in 1718 as an intermediate punishment that would spare the lives of those adjudged undesirable and remove them from British streets. Expulsion had long been used to deport such people, who included vagrants, prostitutes, the poor, and strangers, from towns and communities throughout England. Fueled by the desire to protect the increasing wealth derived from the nation's burgeoning commercial ventures, as well as concerns with rising criminal activity, the Whig government created more capital offenses to deter potential offenders and to protect property, out of which grew the infamous Bloody Code. With the number of criminals in London's jails growing at an alarming rate, and

5. Hunt, Inventing Human Rights; Laqueur, "Bodies, Details, and the Humanitarian Narrative"; Wilson and Brown, Humanitarianism and Suffering, 9-11; Halttunen, "Humanitarianism and the Pornography of Pain," 303-4; Festa, "Humanity without Feathers," 3-4, 13. Festa stipulates that sensibility "designates the susceptibility or sensitivity of a particular individual and is a quality of a subject," sympathy "involves the capacity to feel for or empathize with another and is an interpersonal relation," and sentimentality operates as "a literary form: a rhetorical structure designed both to incite feelings in readers and to direct those feelings toward their 'proper' objects" (7). 
executions and corporal punishment proving ineffective in preventing crime, Parliament sought a new method for handling property offenses and succeeded in passing the Transportation Act with relatively little objection. ${ }^{6}$

The Transportation Act allowed court authorities to banish criminals abroad as punishment, and with this greater discretionary power, they considered the severity of the crime committed and character references given by those in court in deciding the sentence. Initiated by the recorder of London, William Thomson, a keen government supporter, the act allowed British juries, judges, and magistrates to recommend or choose to transport an offender to the American colonies for seven years if found guilty of "Grand or Petit Larceny" or other crimes punishable by whipping, and many of these offenders were sold as convict servants. The act represented a remarkable divergence in modes of punishment for non-capital offenders, who were not subject to the death penalty, since judges could now choose to sentence these offenders to banishment, a punishment that would not be limited to the pardoning process as before. For capital offenders, who could be hanged for their crimes, judicial officials could issue pardons on the condition that those convicted would be transported and sentenced to fourteen years or for life in the colonies. So for less serious offenders, transportation

6. Gwenda Morgan and Peter Rushton, Banishment in the Early Atlantic World: Convicts, Rebels and Slaves (London: Bloomsburg Academic, 2013), 10-11; "An Act for the Further Preventing Robbery, Burglary, and Other Felonies," in John Raithby, ed., The Statutes at Large, of England and of Great Britain: From Magna Carta to the Union of the Kingdoms of Great Britain and Ireland, vol. 8 (London, 1811), 126-27; Ekirch, Bound for America, 1-2, 11-20. In 1597 it was possible for magistrates to banish rogues and vagabonds from England. In 1615, during the reign of James I, capital offenders could obtain pardons to be banished across the ocean. Some malefactors escaped harsher punishments by claiming benefit of the clergy, and others received royal pardons to transport themselves across the Atlantic Ocean, but a number failed to do so or they returned before their sentences were complete. After the War of the Spanish Succession, unemployment increased dramatically in English cities, and poverty and new shops and stocked warehouses tempted many people into thievery. The concern over a rising crime rate resulted in part because of the growth in print culture, particularly the increase in newspaper circulation and the growing numbers of the poor in London and other cities; Peter Linebaugh, The London Hanged: Crime and Civil Society in the Eighteenth Century (London: A. Lane, 1991), 17, 52-53; F. J. McLynn, Crime and Punishment in Eighteenth-Century England (London: Routledge, 1989), xi-x, xii; J. M. Beattie, Crime and the Courts in England, 1660-1800 (Princeton: Princeton University Press, 1986), 450, 470-71, 500-504; J. M. Beattie, Policing and Punishment in London, 1660-1750: Urban Crime and the Limits of Terror (Oxford: Oxford University Press, 2001), 427-30. 
may have seemed harsh, but for capital offenders, the option appeared to be an outwardly humane alternative to the death penalty.

While the law, of course, often served class needs, judicial authorities passed sentences that took into account factors relevant to a case, such as age, poverty, and reputation. Many transportees probably had committed crimes out of economic desperation, but there were some serious malefactors. Overall, most were young males and often unskilled or minimally skilled, although a small number were people of wealth and status (see figure 1). In evaluating cases and meting out punishments, more or less conscientiously, judges and juries considered the practical, Christian, and community elements relevant to the particular circumstances. ${ }^{8}$

7. "An Act for the Further Preventing Robbery, Burglary, and Other Felonies," 126-30; Ekirch, Bound for America, 3, 15-18, 30-34. Authorities had used the death penalty as a deterrent, and for non-capital offences courts punished criminals with brandings, time in the pillory, whippings, short prison sentences, or time in the house of correction; Beattie, Crime and the Courts in England, 470-71, 500-506, 509; Beattie, Policing and Punishment in London, 1660-1750, 424-25, 429-30. The majority of transportees were non-capital offenders. From the extant record, we can conclude that most convicts committed crimes against property. Grand larceny was considered a capital crime, and offenders could receive the death penalty. This transgression consisted of the stealing of goods worth a shilling or more. This excluded stealing from shops, in which the goods equated to more than four shillings, or from homes, in which the goods equated to more than thirty-nine shillings. Petty larceny, which consisted of stealing goods worth less than a shilling, was a non-capital crime, and offenders were penalized mostly with whipping. Differences between these categories broke down with the Transportation Act (as well as with the extension of the benefit of the clergy in 1706), as both kinds of offenders could be penalized with transportation. Further, juries could offer partial verdicts, which would deem offenders culpable of less severe crimes than those they had initially been charged with. After offenders were found guilty, judges could deem noncapital offenders worthy of a lesser punishment other than transportation and could recommend capital offenders for royal mercy, which exiled the malefactor for fourteen years or for life. See Beattie, Crime and the Courts in England, 182, 506, 50913, and Ekirch, Bound for America, 28-33, 55.

8. Douglas Hay argues that Whig elites used the criminal law as a means to enforce their authority over the less powerful through judicial terror or benevolence; Hay, "Property, Authority and Criminal Law," in Douglas Hay, Peter Linebaugh, John G. Rule, E. P. Thompson, and Cal Winslow, eds., Albion's Fatal Tree: Crime and Society in Eighteenth-Century England (New York: Pantheon Books, 1975), 26. Peter King found that people from a variety of different socioeconomic positions, including prosecutors, witnesses, magistrates, and juries, powerfully shaped the outcome of cases; King, "Decision-Makers and Decision-Making in the English Criminal Law, 1750-1800," Historical Journal 27, no. 1 (1984): 26, 45, 51 56-57. From Surrey assize records from 1736 to 1753 regarding those convicted of non-capital 


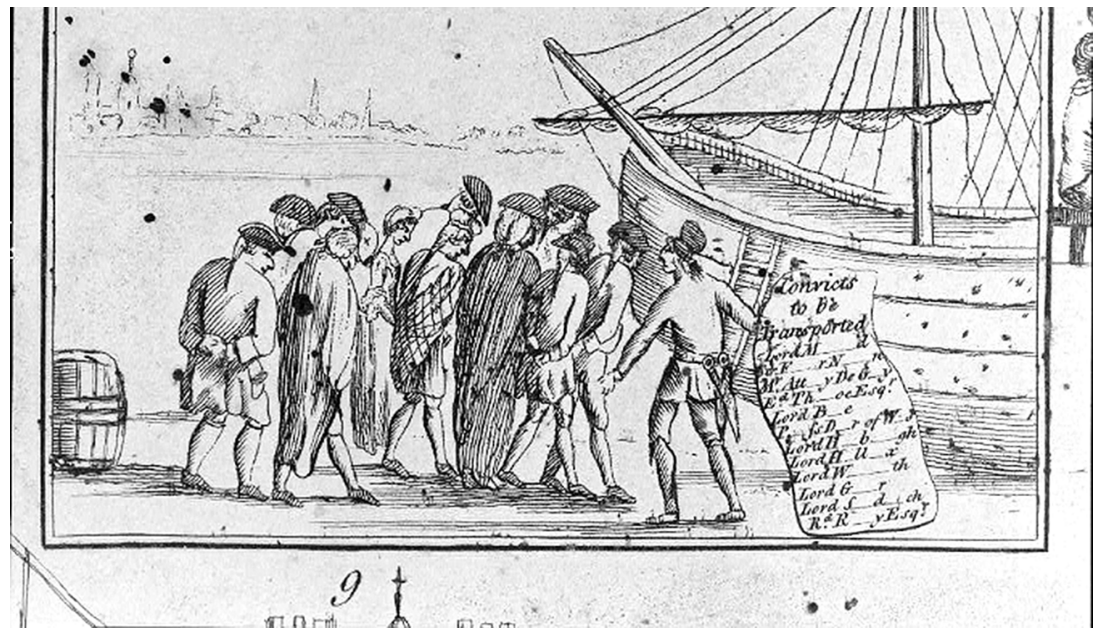

Figure 1. Convicted lords, esquires, and attorneys prepare for transportation. From Richard Whitworth ("Veridicus"), Political Electricity; or, An Historical Eळ Prophetical Print in the Year 1770. Copperplate engraving, 1770. Library of Congress, PC 1-4422A.

Transportation promised an economically efficient option for protecting peace at home while sparing the lives of criminals. Britons argued that corporal punishment failed as a deterrent, and transportation could save money on rewards and was cheaper than maintaining offenders in jail. ${ }^{9}$ Court

larceny, Ekirch found that 62.5 percent of the male convicts were transported, compared to 39.6 percent of the female convicts. He states that women had better prospects of acquittal, and court authorities typically passed transportation sentences in lieu of less severe penalties on the most threatening female offenders. There were, however, regional differences and fluctuations in the proportion of female to male transportees throughout the century; Ekirch, Bound for America, 5, 14, 19, 49-56. See Gwenda Morgan and Peter Rushton, Eighteenth-Century Criminal Transportation: The Formation of the Criminal Atlantic (New York: Palgrave Macmillan, 2004), 46-51; Beattie, Crime and the Courts in England, 509.

9. Benjamin Balak and Jonathan M. Lave, "The Dismal Science of Punishment: The Legal-Economy of Convict Transportation to the American Colonies," Journal of Law \& Politics 18, no. 4 (2002): 883-84, 897-99. Punishing offenders in workhouses and jails was a less attractive option because of the expense. Between 1718 and 1772 the Crown spent over $£ 86,000$ shipping almost 18,000 convicts across the Atlantic. Jonathan Forward, who had worked in the trans-Atlantic slave trade, received the contract in 1718 to ship convicts from London and neighboring counties to the New World, and he initially earned $£ 3$ for each one transported. From 
authorities had the discretion to spare eligible offenders the death penalty, a sentence that while cost-effective and efficient, was not merciful. In 1731 the Reverend George Ollyffe argued that transportation was a way to drain "the Nation of its offensive Rubbish, without taking away their Lives." Ollyffe's use of "offensive Rubbish" suggested the benevolence of judicial authorities in sparing them. Other European governments penalized offenders with imprisonment and hard labor, but Britons could boast that transportation allowed them to reject this punishment, one that many associated with tyranny, at home. By transporting offenders abroad, Britons could claim a dominion of liberty that meanwhile benefited the Treasury. ${ }^{10}$

This penal policy, which relieved the Treasury, removed undesirable people from communities, and spared offenders their lives, nevertheless provoked new and widening moral concerns. Institutional transportation had developed during the period of shifting Enlightenment ideas and moral thinking. The roots of humanitarian sensibility lie in part with the critical Enlightenment philosophies. The famous Scottish moralist Francis Hutcheson noted that God provided people with a "moral sense." Human compassion, he argued, demonstrated that people were not exclusively selfish beings, and he understood compassion as a precursor to moral behavior. Moreover, Hutchinson and his student Adam Smith thought that morality could be better understood by studying human behavior and sentiments rather than biblical writings. Smith argued that sympathy was the best way for people to conduct themselves in social and political arenas in order to better human welfare. Discussions about compassion for sufferers shifted from individual and private spaces to public ones, and many contemporaries began to accept humanitarian deeds-acts of benevolence and the reluctance to administer unnecessarily severe pain to fellow human beings—as essential markers of civilized societies. ${ }^{11}$

1727 until 1772 that subsidy was $£ 5$ for London's convicts and those in neighboring counties. Ekirch, Bound for America, 17-18, 70-71.

10. Beattie, Crime and the Courts in England, 518-19; A. G. L. Shaw, Convicts and the Colonies: A Study of Penal Transportation from Great Britain and Ireland to Australia and Other Parts of the British Empire (Melbourne, Australia: Melbourne University Press, 1977), 21; George Ollyffe, An Essay Humbly Offer'd, for an Act of Parliament to Prevent Capital Crimes, and the Loss of Many Lives; and to Promote a Desirable Improvement and Blessing in the Nation, 2nd ed. (London: J. Downing, 1731), 11-12; Bruce Kercher, "Perish or Prosper: The Law and Convict Transportation in the British Empire, 1700-1850," Law and History Review 21, no. 3 (2003): 532; Ekirch, Bound for America, 3.

11. Atkinson, "The Free-Born Englishman Transported," 92, 100; Margaret Nicola Abruzzo, Polemical Pain: Slavery, Cruelty, and the Rise of Humanitarianism (Baltimore: Johns Hopkins University Press, 2011), 3, 52-54; It is also worth 
Though novels and narratives prompted an emerging humanitarian sensibility, language describing the moral integrity of court authorities shows that some eighteenth-century authorities were concerned less with the idea of suffering from punishment per se, and more with unnecessarily severe punishments. ${ }^{12}$ In a 1743 case, the thief Mary Holmes's sentence was reduced to non-capital punishment; the court record indicates that her "Life is probably owing to the Compassion of the Prosecutrix: For had this Felony been laid to have been committed (as the Fact was) in a Dwelling-House,

reflecting that language too has a history. For instance, bumanely and humankind are not defined in the lexicographer Benjamin Defoe's dictionary in 1735, but they appear in Samuel Johnson's in 1755. Defoe defined bumanity as "Manhood, the Nature and Condition of a Man, Gentleness, Courtesy, Affability, Mildness," and Johnson offered four different definitions: "The nature of man," "Humankind; the collective body of mankind," "Benevolence; tenderness," and "Philology; grammatical studies." Defoe defined compassion as "Pity, a Fellow-feeling, a true Sense of another's Misfortunes," and Johnson defined it as "Pity; commiseration; sorrow for the sufferings of others; painful sympathy." Here, at least in print, the 1755 definition of compassion took on the additional sentiment of an uncomfortable sympathy. See B. N. Defoe, A Compleat English Dictionary. Containing the True Meaning of All Words in the English Language, ... (Westminster, 1735), and Samuel Johnson, $A$ Dictionary of the English Language; in Which the Words Are Deduced from Their Originals and Illustrated in Their Different Significations . . , , vol. 1 (London: W. Strahan, 1755). Long before the rise of the new culture of sensibilities, pain — an important conception to the rise of humanitarianism-had been intricately connected to Christianity. Suffering was the Christian punishment for sin (the word pain comes from the Latin word for punishment, poena), and medieval Christians deliberated on how the undertaking of pain carried a spiritual reward. Pushing back on English Puritanism and Thomas Hobbes's argument that the core of human nature is one of self-interest, Latitudinarians found human beings as naturally sympathetic precisely because good deeds engendered positive feelings. Shaped by their work, the third Earl of Shaftesbury, Anthony Ashley Cooper, who studied Lockean ideas on the connection of sensation and information, asserted that humans were imbued with a moral sense. This sense allowed them to distinguish good actions from malicious ones. Francis Hutchinson identified sympathy as witnessing distress or pain and wishing to relieve it. During the era of new sensibilities, changing conceptions of pain and sympathy prompted human beings to alleviate such suffering. Sympathy, then, was key in promoting benevolence; Clark, "'The Sacred Rights of the Weak," 471, 476, 478; Halttunen, "Humanitarianism and the Pornography of Pain," 303-7; Barnett, Empire of Humanity, 49.

12. Green, "Humanitarianism in Nineteenth-Century Context," 1161-62; Lynn Festa and Margaret Abruzzo have found that some eighteenth-century counterparts were preoccupied less with sufferers' pain and more with upholding their own sense of moral uprightness. See Festa, "Humanity without Feathers," 9-10, and Abruzzo, Polemical Pain, 2, 18. 
it had been a capital Offence." ${ }^{13}$ Judicial authorities did not believe that Holmes deserved a lesser charge, but they spared her life regardless and sentenced her to transportation. Compassion here took on a didactic tone that allowed court officials to articulate an alleged sympathy and benevolence for a legally undeserving prisoner. In 1748 Thomas Bacon was charged with taking buckles, handkerchiefs, a mirror, and five pounds belonging to his mother. He was fortunate to receive transportation as punishment since "The Foreman of the Jury said that the reason of their bringing in so favourable a verdict was, out of compassion to the mother and the family, and not in regard to the prisoner." ${ }^{14}$ The court thus based its decision on pity and perhaps concern for the family, although the sentence could have been more severe.

Transportation became a way to spare some convicts the lives that they could have lost through crime, and some courts linked transportation with notions of individual reform. To be sure, transportation was largely thought of as a deterrent to discourage potential malefactors. It was not institutionally designed either to reform criminals or to generate much-needed labor in the colonies. Transportation was designed primarily, after all, to assist Britain with its agenda at home rather than in colonial settlements. Nevertheless, some court officials suggested that criminal reformation was a reason or a consequence of their sentencing..$^{15}$ In 1743 , when young Thomas Broxton stole a "Pebble Snuff-box" worth seven pounds, "The Jury recommended him to the Court for corporal Punishment; but the Court was of Opinion, that it was doing the Boy a great Piece of Service to send him abroad." Broxton was probably around thirteen years old since his baptismal certificate, dated February 1730, was produced in court. The court may have considered that he might change his criminal behavior in the colonies. ${ }^{16} \mathrm{In}$

13. Trial of Mary Holmes, otherwise Yates, other wise Smith, June 29, 1743, Old Bailey Proceedings Online, www.oldbaileyonline.org, t17430629-28.

14. Trial of Thomas Bacon, September 7, 1748, Old Bailey Proceedings Online, www.oldbaileyonline.org, t17480907-55.

15. Ekirch concludes that there is actually little evidence to support the notion that courts seriously considered colonial labor shortages when deciding to transport criminals; Ekirch, Bound for America, 16-19, 44-45.

16. Trial of Thomas Broxton, January 14, 1743, Old Bailey Proceedings Online, www.oldbaileyonline.org, t17430114-8. According to this record, children under seven years old were largely found innocent of accused felonies. If the child offender was between ages seven and twelve years old, courts judged whether he or she had knowledge of the maliciousness of the felony. The courts probably found many young offenders innocent "because he is supposed not of Discretion to judge 
1728 Lord Chief Justice Raymond recommended a reprieve for a capital offender, Francis Tweed, with the "condition of Transportation." He based the decision on the fact that Tweed was young, from a respectable family, "gave great assurances of Reformation," and could become, as petitioners on his behalf urged, "a new man." ${ }^{17}$ Another offender faced the death penalty for prematurely returning from transportation, but he pleaded with the court to allow him to go abroad, stating, "I hope I shall become a new man." Although this offender was no doubt trying to avoid the gallows, his pledge — as did Raymond's report on Tweed — to become a "new man" suggests that he understood transportation advanced at least some goals of refiguring criminal behavior. ${ }^{18}$

Colonists noted that some convicts did in fact reform in the colonies. Reflecting on the earlier practices of convict servitude, one traveler, Edward Kimber, noted, "Several of the best Planters, or their Ancestors, have, in the two Colonies, been originally of the Convict-Class, and therefore, are much to be prais'd and esteem'd for forsaking their old Courses." He acknowledged transportation's success in providing the vehicle for convicts to reform and become productive members of society. ${ }^{19}$ Judicial sentences were rooted in economic or social benefits to the community, yet the discretionary power in the law allowed authorities to presume a new moral responsibility in defending their choice to sentence offenders abroad.

\section{SERVITUDE, SYMPATHY, AND SLAVERY}

By the second half of the eighteenth century, convict transportation and servitude evoked new discussions on punishment, reform, and morality, which informed and overlapped new discourse on the practices of both penal labor and African slavery in revealing ways. Lurid accounts of the voyage crossing the Atlantic increased sympathies for transportees. An estimated 14 percent of convicts died during the passage, owing largely to

between Good and Evil," and sentenced them to the death penalty only if the evidence and situation showed that the malefactor did indeed have discretion.

17. National Archives Online Catalogue: SP 36/7/2 f. 67: Secretaries of State: State Papers Domestic: George II, 1718-1760, vol. 7 [73]: Letters and Papers, June-July 1728, July 24, 1728, Kew, U.K.: National Archives of the U.K., 2013; Beattie, Crime and the Courts in England, 509.

18. Trial of John Jettea, February 21, 1753, Old Bailey Proceedings Online, www.oldbaileyonline.org, t17530221-45. Jettea lost his case and was sentenced to death.

19. Edward Kimber, Itinerant Observations in America, ed. Kevin J. Hayes (Newark: University of Delaware Press, 1998), 50-51. 
crowded and unsanitary conditions. Meanwhile, convicts were at the mercy of the ship's captain and crew, as well as the weather. In 1768, for example, the Gentleman's Magazine reported that a storm drove a convict ship destined for Maryland all the way to Antigua, where the "poor wretches" finally arrived "in the most deplorable condition, full of sores, almost starved, and cover'd with vermine." Eleven died because of lack of provisions, and the others "had eaten their shoes" to survive. In this account, a tension emerges between crime and victimhood that evokes a sense of pity for malefactors who had little control over their fates. ${ }^{20}$

Merchants, of course, had an economic incentive to keep mortality rates low, since the more transportees they could sell, the more profits they made. But some apparently expressed an authentic sympathy toward convicts. Andrew Reid remarked that he was "grieved so many healthy young People die in the Voyage," and other merchants registered shock at the cruelty involved in transporting offenders. One observer exclaimed that "all the states of horror I ever had an idea of are much short of what I saw this poor man in; chained to a board in a hole not above sixteen feet long, more than fifty with him; a collar and padlock about his neck, and chained to five of the most dreadful creatures I ever looked on." ${ }^{11}$ This visualization of "horror" and suffering affirmed that the punishment was not proportional and struck this observer as too severe- hitherto, unimaginable to him.

Transportees and observers also described the punishment as dehumanizing and akin to the treatment of animals. Arriving in Maryland in 1762, the young William Green described his grim experience, explaining that upon arrival, all the transportees were put in chains and "drove in lots like oxen or sheep" to be sold as convict servants. Prospective colonial buyers, he explained, would "search us there as the dealers in horses do," examining limbs and teeth to assess health and to ensure the convicts would be able to perform the intended labor. Readers of this account could thus visualize the dehumanizing practice of convict servitude that drew sympathy for offenders while warning against a life of crime. ${ }^{22}$

20. Aaron S. Fogleman, "From Slaves, Convicts, and Servants to Free Passengers: The Transformation of Immigration in the Era of the American Revolution," Journal of American History 85, no. 1 (1998): 55-56; Gentleman's Magazine, and Historical Chronicle, May 1768, 241.

21. Ekirch, Bound for America, 97, 108; unattributed quote in Basil Sollers, "Transported Convict Laborers in Maryland during the Colonial Period," Maryland Historical Magazine 2 (1907): 41n1.

22. William Green, The Sufferings of William Green: Being a Sorrowful Account, of His Seven Years Transportation, Wherein Is Set Forth the Various Hardships He Underwent . . (London: J. Long, 1774 [?]), 4-6. 
This rhetoric of dehumanization was used not only by convicts, but also by colonial observers who wished to end the trade. For years American colonists worried about convicts' moral character and their potential for recidivism. In 1751 Benjamin Franklin bitterly proposed that "Rattle-Snakes seem the most suitable Returns for the Human Serpents sent us by our Mother Country." Contrary to many colonists' arguments about convicts' recidivism in the colonies, the proportion of these offenders who were indicted for illegal acts was probably small. Historians have found that the growth of print culture after the 1720s probably helped spread the notion that many more committed crimes in the colonies, or ran away to return to England, than actually did. Nevertheless, concerned colonists defended their moral priorities and distanced themselves from these penal laborers by drawing attention to their alleged inhuman traits. ${ }^{23}$

Some Britons suggested that transportees' new lives in the colonies afforded them an opportunity to reform, but many colonists scoffed at the idea of transportation as rehabilitative and focused their moralist critiques on altering or ending the trade. In 1721, in the American Mercury, one writer mentioned, "We hear, that several of our Merchants Ships have declined carrying any more Felons to the Plantations," as convicts were "serviceable to the Planters; yet they are so notoriously guilty in corrupting the People there, that the Country are heartily weary of them." ${ }^{24}$ Even though there was a market for convicts, this author felt that they did not benefit society as a whole. Some colonists argued that convicts encouraged others to embark on criminal paths. In 1740 the Virginia planter William Byrd II complained that the "vile commodity" of convict servants discouraged the immigration of honest people and encouraged crime, creating new "enimies to mankind." Byrd heatedly asserted that these laborers were the criminal contagions and moral outsiders. He felt that transportation's inherent disproportionality as a punishment, which rewarded criminals with a better life in Virginia, rather than punishing them in their home communities, encouraged malefactors to cause damage, steal, or inflict harm on others. Penal hard labor on public works, Byrd contended, was a better

23. Benjamin Franklin, "To the Printers of the Gazette," Pennsylvania Gazette, May 9, 1751, emphases in original; Morgan, "English and American Attitudes towards Convict Transportation," 417; Ekirch, Bound for America, 169-77; Gwenda Morgan and Peter Rushton, "Running Away and Returning Home: The Fate of English Convicts in the American Colonies," Crime, Histoire E̊ Sociétés/Crime, History EO Societies 7, no. 2 (2003): 62-63, 75-76.

24. "London, May 20," American Weekly Mercury, August 31-September 7, 1721. 
punishment than transportation and servitude, as it benefited society and discouraged other malefactors. ${ }^{25}$

Though colonists derided convicts' moral character, many increasingly purchased these offenders, which added to the concerns regarding human bondage. With the construction of a highly productive Atlantic system, its burgeoning commercial economy relied on free and unfree laborers. Convict labor that provided house servants, artisans, unskilled workers, and field hands grew alongside African chattel slavery. Convicts occupied a different legal status from other unfree laborers and were not subjected to the harsh and painful racial prejudice experienced by enslaved Africans. But colonial records do show that convicts shared similar poor accommodations and inadequate food and clothing, while harsh working environments, maltreatment, and disease also exacerbated the difficulties of both convicts and the enslaved. Colonists purchased these offenders throughout the century, and the accounts of their punishment evoked increasing sympathies for those banished and sentenced to terms of bondage. Interlocutors also cited the punishment while discussing their stance for or against chattel slavery. Thus, as slavery became, in David Brion Davis's characterization, a "problem" among many Europeans and colonists in the late eighteenth century, so too did convict transportation. ${ }^{26}$

Though there were clear legal and cultural differences between perpetual chattel slavery and convict servitude, contemporaries occasionally likened the latter to a form of slavery. Ideas of race underpinned understandings of colonial life: white colonists increasingly relegated Africans to categories of inferiority. Meanwhile, convicts epitomized the social vices of society, including depravity, violence, and destitution. Recently, historians have been arguing that though there were distinctions in forms of unfreedom,

25. William Byrd to Mr. Smyth, September 6, 1740, in The Correspondence of the Three William Byrds of Westover, Virginia, 1684-1776, ed. Marion Tinling, 2 vols. (Charlottesville: The University Press of Virginia, 1977), 2:556-57.

26. Morgan and Rushton, Eighteenth-Century Criminal Transportation, 143-44; David Brion Davis, Inhuman Bondage: The Rise and Fall of Slavery in the New World (New York: Oxford University Press, 2006), 77-81, 102, 130-31, 181-82, 246-48; Halttunen, "Humanitarianism and the Pornography of Pain," 303, 305, 307; Ekirch, Bound for America, 142, 145-52. Less wealthy planters in particular may have found convict laborers more attractive because they were generally cheaper than enslaved people, and they usually had longer periods of service than indentured servants; see Ekirch, Bound for America, 124-25. Fogleman, "From Slaves, Convicts, and Servants to Free Passengers"; also see Davis, The Problem of Slavery in Western Culture. 
examining the variations of coerced labor and human bondage illuminates an intricate system of Atlantic "slaveries." This analytical framework reveals how these forms of bondage informed early efforts to justify or abolish different labor institutions. ${ }^{27}$ Convicts sometimes drew on the language of slavery in their attempts to avoid transportation or further punishment. In 1721 a returned transportee, Henry Woollford, claimed "he had just Reason to come Home; because the Law was not ... that they should be in such a manner sold for Slaves, which was worse than Death, being Christians by Baptism." Woollford distanced himself from slavery on the basis that he was a Christian and, therefore, undeserving of such a punishment. His "just Reason" implies that the punishment was illegitimate because it was, in his view, a form of slavery. ${ }^{28}$

Other offenders, like Edward Williams, the thief who took the sheepskins and buckskins, begged the courts for punishment inside their own country. Some even requested to be hanged instead of transported. When John Read received an execution sentence for returning from transportation, he was grateful; he declared that "he would rather die than live a transport, as no man knew the misery of such a state, but those who felt it." Read reported that he planned to hang himself if he could not escape from "his slavery and bondage," which he considered worse than living. ${ }^{29}$ Another offender worried about working as a servant and "presented a petition to be hanged" rather than be transported. He would "rather bear strangling for a minute," he averred, "than to make sugar all his life-time." Convicts clearly knew how transportation operated as well as its harsh reputation, which, over time, some deemed worse than staying alive. ${ }^{30}$

27. Ekirch, Bound for America, 151. Historians have increasingly called for scholars to study Atlantic slavery and its multiple forms on a spectrum of unfreedom. See Newman, A New World of Labor, 2-3; John Donoghue, "'Out of the Land of Bondage': The English Revolution and the Atlantic Origins of Abolition," American Historical Review 115, no. 4 (2010): 943-74, especially 944-45; Peter Kolchin, "Introduction: Variations of Slavery in the Atlantic World," William and Mary Quarterly 59, no. 3 (2002): 551-54.

28. Ordinary of Newgate's Account, April 3, 1721, Old Bailey Proceedings Online, www.oldbaileyonline.org, OA17210403.

29. Ordinary of Newgate's Account, June 4, 1770, Old Bailey Proceedings Online, www.oldbaileyonline.org, OA17700604.

30. London Magazine, or, Gentleman's Monthly Intelligencer, December 1768, 640. Some offenders asked for alternative punishments, including whippings or military service in place of banishment. A few even volunteered for medical experiments. In 1721 medical researchers performed smallpox experiments on six convicts, and they would receive pardons in return; see Ekirch, Bound for America, 62-63. 
The notion that guilty criminals should be penalized received broad support, but the severity of the punishment of transportation, especially the mechanism of banishment, elicited sympathy and criticisms in a culture of widening enlightened sensibilities. A contributor to Felix Farley's Bristol Journal in 1774 discussed the problems with transportation, citing the case of two sisters condemned to the punishment. He drew attention to the younger one, who would be "Banished from all her Friends, an affectionate Mother, and other Ties more tender, to a foreign Country." The author stated that this situation should "naturally engage the Interest of every benevolent Reader" and promote a "Sense of Sympathy," and he affirmed, "let the Hearts of every benevolent Person plead for her in the Cause of Humanity." ${ }^{11}$ In the early 1770s, the lawyer Henry Dagge argued that banishment for convicts was "very difficult to justify ... on the footing of sound policy" because the sentence merely transferred the problem to another place rather than remedying it. To him, "death, imprisonment, or banishment" was more an act of "gratification of revenge, than a retribution," as "The suffering of the criminal" does little good for the offender or society. ${ }^{32}$ The social reformer Jeremy Bentham shared this perspective, arguing that with banishment, "nothing can be more unequal than the effect which the change of country has upon men of different habits, attachments, talents, and propensities." Transportation was "a very afflictive train of preliminary hardships" that brought a premature death to some offenders. ${ }^{33}$ The convict trade was not only becoming more complicated to justify, but it was also developing into an increasingly problematic humanitarian issue in which criminal reform needed to be addressed more directly and urgently.

By midcentury, a widely perceived crime problem was drawing popular attention, and the Italian economist Cesare Beccaria's tract On Crimes and Punishments made an indelible mark on these debates. Beccaria condemned capital punishment-significant for reformists' philosophies-and argued for proportional punishment for crimes. Heavily influenced by Beccaria, the

31. Felix Farley's Bristol Journal, April 16, 1774; Morgan and Ruston, Eighteenth-Century Criminal Transportation, 61.

32. Henry Dagge, Esq., Considerations on Criminal Law, 2nd ed., 3 vols. (London: T. Longman and T. Cadell, 1774), 2:182-83, 1:217-18; Morgan, "English and American Attitudes towards Convict Transportation," 423.

33. Jeremy Bentham, A View of the Hard-labour Bill; Being an Abstract of a Pamphlet, Intituled "Draught of a Bill, to Punish by Imprisonment and Hard-Labour, Certain Offenders; and to Establish Proper Places for their Reception," . . (London: T. Payne and Son, 1778), 3. 
conservative jurist William Blackstone noted that the purpose of punishment must be to correct criminal behavior, so punishment must fit the crime committed. The criminal law, he argued, should be based on "principles that are permanent, uniform, and universal" and should conform to "the feelings of humanity, and the indelible rights of mankind." He found that execution, as well as "perpetual disability by exile, slavery, or imprisonment" should be imposed only on "incorrigible" offenders. Blackstone argued that the king's pardons, many of them predicated on offenders' transportation, were meant "to make the offender a new man; to acquit him of all corporal penalties and forfeitures... and not so much to restore his former, as to give him a new, credit and capacity." ${ }^{34}$ The troubled rapport between banishment and reform revealed a misalignment between punishment and emerging notions of proportionality. If the law was to be executed with "feelings of humanity," it would have to reconcile with projected ideals and contemporary practices.

The problem of convict servitude piqued colonists' sentiments on the moral corruptibility of other unfree laborers, as well as their fears of insubordination and violence. One Maryland letter writer thought that convicts corrupted the morals of enslaved people and indentured servants, thus provoking insubordination. Meanwhile, colonial legislators sometimes legally grouped enslaved people and convict servants together. A 1765 Maryland law stated that "any Convict servant, Negro, or other slave" found off a plantation with a dog could receive up to fifteen "Stripes on his Naked Back." This law not only reinforced convicts' distinct and inferior status in the colonies, but also coded the colonists' superiority over both criminals and blacks, thereby both elevating their sense of moral worth and legitimizing separateness. And according to Virginia Councilors Thomas Lee and William Fairfax, "it has been truly said that Freedom wears a Cap that can without a Tongue call together all those that long to shake off the Fetters of Slavery." Lee and Fairfax feared that "when the Imports of Convicts under these Encouragements are sufficiently increas'd who are wicked enough to join our Slaves in any Mischief," their collusion would probably "bring sure and sudden Destruction on all his Majesty's good Subjects of

34. Beattie, Crime and the Courts in England, 554-58; Cesare Beccaria, "An Essay on Crimes and Punishments" (1764), in Isaac Kramnick, ed., The Portable Enlightenment Reader (New York: Penguin Books, 1995), 525-32; Morgan, "English and American Attitudes towards Convict Transportation," 422; William Blackstone, Commentaries on the Laws of England. Book the Fourth (Dublin: John Exshaw, Henry Saunders, et al., 1770), 3, 11-12, 394-95, emphasis in original. 
this Colony." ${ }^{35}$ Colonists thus disparaged convict servants and the trade, while asserting their own moral standing through law, status, and discourse.

The focus on the sufferings and sympathies associated with the convict trade informed discussions on African slavery. At the same time colonists and Britons debated the convict trade, the antislavery movement gained steam through the popularization of the eighteenth-century campaign, as Christopher Brown argues. John Donoghue has encouraged scholars to investigate how other forms of labor, such as the seventeenth-century practice of convict servitude, contributed to the early sentiments that condemned unfreedom. ${ }^{36}$ Eighteenth-century commentators used the convict trade as a didactic device to help illuminate the reasons that contemporaries, in the words of one observer, found that the "most wretched Slavery . . . would render the life of any humane man most miserable." The abolitionist Granville Sharp's well-known work, The Just Limitation of Slavery in the Laws of God, contains an anonymous letter that exposes the horrid disciplinary measures that both enslaved people and convicts endured: "The punishments of the poor negroes and convicts, are beyond all conception." The writer goes on to assert that "they are often punished for not doing more than strength and nature will admit of." He describes how "One common punishment, is to flea their backs with cow hides, or other instruments of barbarity, and then pour on hot rum, superinduced with brine or pickle, rub'd in with a corn husk, in the scorching heat of the Sun." The letter then declares, "For certain, if your judges were sensible of the shocking treatment of the convicts here, they would hang every one of them, as an infinitely less punishment, and transport only those, whose crimes deserve the severest death. Better be hanged seven hundred times, than serve seven years here!" Such sentiments, printed in the work of one of the most important leaders of the early antislavery campaign, offered a powerful denunciation of the unjust pain and brutal physical punishment meted out to unfree laborers in the colonies. Convict servitude and African slavery had turned the colonists into "savage and brutal masters" in a tract that drew sympathy

35. Frederick H. Schmidt, "British Convict Labor in Colonial Virginia" (Ph.D. diss., College of William and Mary, 1976), 5; Virginia Gazette, May 30, 1751; Archives of Maryland: Proceedings and Acts of the General Assembly of Maryland, vol. 59, 1764-1765, ed. J. Hall Pleasants (Baltimore: Maryland Historical Society, 1942), 277; H. R. McIlwaine, ed., Legislative Journals of the Council of Colonial Virginia, 3 vols. (Richmond, Va.: Colonial Press, Everett Waddey Co., 1918), 2:1034-35; Ekirch, Bound for America, 138.

36. Brown, Moral Capital; Donoghue, "'Out of the Land of Bondage."” 
for those in unfree conditions. Drawing parallels with white convict servitude perhaps helped readers better understand and empathize with the horrors of African chattel slavery, a system "abhor[red] and abominate[d]" by the author, who concluded, "If I had a child, I had rather see him the humblest scavenger in the streets of London, than the loftiest tyrant in America, with a thousand slaves at his beck." ${ }^{37}$

Antislavery advocates on both sides of the Atlantic used convict servitude as a lever to distance themselves from slavery and to claim greater moral civility. Granville Sharp thus influenced many leading abolitionists and moralists, including Anthony Benezet, Benjamin Franklin, and Benjamin Rush. The British antislavery advocate James Ramsey shared the sentiment that convicts and enslaved people endured unnecessarily severe cruelties at the hands of colonists. Ramsay thought that American planters treated indentured servants and "their African slaves and English convicts ... with full as much severity as was practiced only on Africans in the sugar islands," and he argued that this cruelty showed their lack of moral responsibility toward unfree laborers. ${ }^{38}$ This trans-Atlantic dialogue underlined a national difference: British antislavery advocates emphasized the inhumane violence of American slavery, whereas white Americans discussed the degrading effect of unfree people on their soil.

Some early antislavery voices offered alternatives to convict servitude and slavery. The well-known trade theorist Malachy Postlethwayt denounced the African slave trade and was also apprehensive about the traditional practices of the convict trade. He explained, "We have prodigious numbers of vagabonds," and he thought that "there cannot therefore be any cruelty in sending these people, where they shall be compelled to labour, and thereby maintain themselves, and become useful to others." Others in England were minor criminals for whom "it would certainly be good policy, as well as charity, to put them in the way of honest labour." But he did not want them

37. Granville Sharp, The Just Limitation of Slavery in the Laws of God, Compared with the Unbounded Claims of the African Traders and British American Slaveholders (London: B. White and E. and C. Dilly, 1776), appendix 2, 42-43, emphases in original; Brown, Moral Capital, 93, 172-73, 175, 179-80. Brown notes that Sharp did not circulate materials on the cruelty of slavery to evoke emotions, as that would have positioned the campaign as philanthropic. Rather, he found it a moral responsibility to do so because slavery defied the laws of God.

38. Daniel B. Wallace, Granville Sharp's Canon and Its Kin: Semantics and Significance (New York: Peter Lang, 2009), 36; James Ramsay, An Essay on the Treatment and Conversion of African Slaves in the British Sugar Colonies (London: James Phillips, 1784), 36. 
to be sent over "like transports or negroes," arguing that they should not be tainted with "shame" and should have "as little of compulsion as may be." $\mathrm{He}$ assured his readers that there were enough Britons with "liberal hearts as well as weighty purses" who could sponsor such a benevolent project across the Atlantic. ${ }^{39}$ Postlethwayt's anti-slave trade views did, however, aim to expand British imperialist endeavors in Africa, whose wealth he hoped England could access through political stability that could not be achieved while the demand for enslaved people persisted. Nevertheless, early abolitionists relied on his writings to rethink the morality and economic efficiency of the slave trade and labor organization. In 1764 the well-known Virginia antislavery advocate Arthur Lee-a son of Councilor Thomas Lee-published An Essay in Vindication of the Continental Colonies of America in response to Adam Smith's Moral Sentiments, which mocked colonists as the "refuse of jails." Lee condemned the African slave trade while citing Postlethwayt's argument that the colonies would be better off being populated with Europeans. ${ }^{40}$

Arguments also emerged promoting convict servitude as a solution for ameliorating slave conditions in the Caribbean. After arriving in Barbados in 1780, a British plantation owner, Joshua Steele, writing under the pseudonym Philo-Xylon, began offering suggestions for improving the system of slavery there. With the creation and support of a learned institution, the Barbados Society for the Encouragement of Arts, Manufactures and Commerce, Steele argued for and even instituted ameliorative changes to plantation management strategies. On his own plantations he prohibited the punishment of whipping and rented land and offered wages to enslaved people. Although local planters opposed Steele's plantation strategies, which they felt destabilized the racial hierarchy, the British abolitionist Thomas Clarkson praised his reform efforts and hoped they would be an example for other plantations. In considering economic growth on the island, Steele knew that replenishing the enslaved population was costly,

39. Brown, Moral Capital, 209, 274, 322; Morgan and Rushton, EighteenthCentury Criminal Transportation, 128-29; Malachy Postlethwayt, The Universal Dictionary of Trade and Commerce, Translated from the French of the Celebrated Monsieur Savary . . , 2 vols. (London: John and Paul Knapton, 1751-55), 1:534, at the Library Company of Philadelphia.

40. Brown, Moral Capital, 270-74, 321-22; Arthur Lee, An Essay in Vindication of the Continental Colonies of America, from a Censure of Mr Adam Smith, in His Theory of Moral Sentiments (London: T. Becket and P. A. De Hondt, 1764), 9-10, 30, 45-46; Morgan and Rushton, Eighteenth-Century Criminal Transportation, 147. 
and he suggested that the slave trade could be supplemented with convict laborers. "This Proposition implies a compassionate Feeling for the innocent, but oppressed Africans, on one Hand; and a Degree of revengeful Aversion against our own incorrigible convict Countrymen, on the other." Thus, the convict trade was a solution that demonstrated sympathy toward enslaved people while forcing criminals to pay their dues to society. Steele, of course, was concerned primarily with diversifying the economy there. The island relied largely on sugar production and had almost no manufacturing sector that could provide work for poor whites living there. Poor relief was expensive to fund, and planters' harsh treatment of the enslaved meant additional costs. "Evils arising from Negro Slavery," Steele claimed, resulted from a division "between black and white Servants; which puts the former, and all their Race, out of the Protection of the Laws of Humanity." If convicts arrived, they would exploit this condition: "their disdaining to Work with Negroes, would provoke Punishments, which in their Turn, would excite Rebellions." Local whites would then come to regard convicts with alarm and disgust. "Therefore, it is not merely Humanity, or Piety, in the Hearts of the Planters, which are wanting to Rectify what is amiss;- - but it is, a total Alteration of the local Laws, agreeable to the Dictates of Humanity and Piety." ${ }^{41}$ Convict labor would thereby become both a righteous and humanitarian means to mitigate the economic and social hardships in Barbados.

For their part, proslavery advocates drew comparisons between the convict and slave trades to validate and further their agendas. Before the American Revolution, the proslavery advocate Edward Long used the convict trade to justify what he described as African nations' mechanisms for commodifying criminals and their role in the slave trade. Long asserted that African states had the same right to sell their offenders as the English did, arguing, "In England, multitudes are hanged, and many more sent to the plantations and sold into slavery; some for a term, others for life." The sale of African convicts was a practice that he thought was "agreeable to the principles of humanity ... [because] captives also should be exiled, rather

41. David Lambert, White Creole Culture, Politics and Identity during the Age of Abolition (Cambridge: Cambridge University Press, 2005), 41-43, 50, 53-57, 68; Philo-Xylon (pseud.), Letters of Philo-Xylon: First Published in the Barbados Gazettes, during the Years 1787 and 1788. . . (Barbados: Thomas Wilmott Perch, 1789), 51, emphasis in original; Morgan and Rushton, Eighteenth-Century Criminal Transportation, 155-56. 
than cruelly tortured to death." Long noted that the loss of life as a punishment was not reformative. ${ }^{42} \mathrm{He}$ drew on the rehabilitative feature of punishment, a theme rooted in the Enlightenment reform measures that had an uneasy history with institutional banishment in the British Atlantic.

The distress of the English poor became a prominent theme in proslavery discourse. In the 1780s, the planter Gilbert Francklyn claimed that accounts of widespread cruelty toward West Indian enslaved people were largely unfounded, but if there were individuals "capable of treating their slaves, their fellow creatures, with cruelty," he suggested that "the planters may be allowed humbly to hope their numbers may not be augmented by Great Britain unloading her gibbets, or emptying her gaols into them, in order to furnish the planters with industrious labourers, in the stead of the negroes meant to be emancipated." 43 Defenders of slavery used convict servitude as a possible consequence for those disrupting the institution and as a strategic tool to bolster arguments about their commitment to human welfare.

Banishment was central to the punishment, and yet it raised a troubling moral problem for many Britons and Americans. Thomas Clarkson attacked the proslavery argument by stating that African criminal commodification was unjust, and it was neither proportional nor humane. No punishment was worse than losing one's liberty, he posited, especially since it was often combined with "the agonizing pangs of banishment"-which encompassed the exclusion of "local," "personal," and "national attachments of mankind," as well as severe corporal punishment. No crime deserved such abuse, Clarkson argued. ${ }^{44}$

42. Edward Long, The History of Jamaica; or, General Survey of the Antient and Modern State of That Island: With Reflections on Its Situation, Settlements, Inhabitants, Climate, Products, Commerce, Laws, and Government, 3 vols. (London: T. Lowndes, 1774), 2:390-91, at the Library Company of Philadelphia.

43. Brown, Moral Capital, 370; Gilbert Francklyn, Observations, Occasioned by the Attempts Made in England to Effect the Abolition of the Slave Trade; Sherwing, the Manner in Which Negroes Are Treated in the British Colonies in the West-Indies . . . (London: Logographic Press, 1789), xviii, emphasis in original. For a discussion of the comparison of the convict trade to Australia and the slave trade, see Emma Christopher, "'The Slave Trade Is Merciful Compared to [This]': Slave Traders, Convict Transportation, and the Abolitionists," in Emma Christopher, Cassandra Pybus, and Marcus Rediker, eds., Many Middle Passages: Forced Migration and the Making of the Modern World (Berkeley: University of California Press, 2007): 10928, esp. 113-14.

44. Brown, Moral Capital, 3-4; Thomas Clarkson, An Essay on the Slavery and Commerce of the Human Species . . (Philadelphia: Joseph Crukshank, 1786), 59-64, emphases in original. 
Debates for and against banishment and penal servitude circulated throughout the Atlantic world, heightening moral tensions surrounding exile and coercion. The well-known Philadelphia physician and reformer Benjamin Rush weighed in against perpetual banishment as a legal punishment, considering "it the next in degree, in folly and cruelty, to the punishment of death." He argued that "Exile, when perpetual, by destroying one of the most powerful principles of action in man, viz. the love of kindred, and country, deprives us of all the advantages, which might be derived from it, in the business of reformation." ${ }^{45}$ Such discourse surrounding legal banishment and punishment by servitude empowered opposition against what increasingly was considered inhumane practices, and it prompted new discussions on the parameters of moral responsibility by elites and reformers.

\section{TRANSPORTATION DEBATES AND MORAL RESPONSIBILITY}

With increasing concerns about crime, poverty, and coerced labor, Britons engaged in new legislative efforts regarding transportation. Demobilization and high unemployment that followed the periods after the War of the Austrian Succession and the Seven Years' War left many men with little money or in debt, and some stole to survive. But elites thought that there were opportunities to find work, and they thus perceived the plight of the poor as less a social problem and more a result of unruliness, idleness, and immorality. Such social ills, they thought, endangered property and social peace while discouraging wage labor. Parliament responded to these anxieties, in part, by introducing the Murder Act in 1752, which allowed judges to order the execution of some guilty offenders within two days of their sentencing, thereby narrowing the time for appeal. This measure was meant to heighten fear of the gallows and discourage potential malefactors, but it did not solve the crime problem. Consequently, during the 1750s and 1760s, merchants carried more transportees than in previous decades, and in 1766 Scotland received the same legal mechanisms for transportation. The convict trade thus served as a safety net for the crime problem and an outlet for removing malefactors. ${ }^{46}$

45. Brown, Moral Capital, 137; Benjamin Rush, An Enquiry into the Effects of Public Punishments upon Criminals, and upon Society (Philadelphia: Joseph James, 1787), 16.

46. Beattie, Crime and the Courts in England, 520-21; Hay, "Property, Authority and Criminal Law," 26; Nicholas Rogers, "Confronting the Crime Wave: The Debate over Social Reform and Regulation, 1749-1753," in Lee Davison, Tim Hitchcock, Tim Keirn, and Robert B. Shoemaker, eds., Stilling the Grumbling Hive: The Response to Social and Economic Problems in England, 1689-1750 (New York: St. Martin's Press, 1992), 78-80, 82-84, 87-88. Newspapers exacerbated fears, and 
Substitutes for transportation, meanwhile, drew condemnation for their lack of proportionality. In 1752 Parliament debated proposing a bill that would offer hard labor on domestic docks, rather than transportation, to some offenders. The bill never passed through the House of Lords. The idea of using malefactors on the docks instead of law-abiding workers raised serious concerns. A writer in the Gentleman's Magazine argued that if felons were confined to work in the dockyards, they would "be distinguished from the artificers employed there by habit, chains, and other marks of slavery," and he claimed "that, to confine such persons to labour" was "even more severe than immediate execution!" 47 Such language criticizing the idea of domestic hard labor drew displeasing parallels between convicts and slaves, and commentators remarked on the injustice of a form of slavery for white convicts at home. One anonymous writer argued that the purpose of punishment was to deter potential malefactors "and, in most Cases, to reclaim the Offender also." The writer thought, moreover, that planters in the colonies offered malefactors a new life of industry under careful supervision and provided them with freedom dues, a custom that obliged owners to give servants goods, such as clothes and tools, after they completed their term of labor. At home, the author contended, offenders would not have this aid after their service, and the authorities who supervised their work "may too easily degenerate into Cruelty" given enough discretionary power over offenders. The writer thought that domestic convict servitude was too costly and drew on ideas of moral reform to bolster the proposed agenda. ${ }^{48}$

Consideration was given to other labor projects for offenders that could be deemed more humane. The Earl of Halifax, for example, contemplated expanding convict transportation in order to decrease executions. Instead of using the traditional means of convict servitude, however, he thought offenders should work on public works in the colonies for the benefit of the community. But a Board of Trade inquiry found no projects that could

those focusing on violent crimes frequently reported on illegal acts involving the wealthy. This was driven in part because robberies of propertied classes garnered readership and criminals sometimes simply found it more profitable to rob the rich; Morgan and Rushton, Eighteenth-Century Criminal Transportation, 143-44, 147-48; Ekirch, Bound for America, 22-23, 25-26, 86.

47. Balak and Lave, "The Dismal Science of Punishment," 896; Ekirch, Bound for America, 226-27; Gentleman's Magazine, and Historical Chronicle, July 1752, 8182, 325-26, emphasis in original.

48. Anonymous, A Letter to a Member of Parliament (N.p.: n.p., 1752), emphasis in the original; Rogers, "Confronting the Crime Wave," 89; Atkinson, "The FreeBorn Englishman Transported," 101. 
provide "so desirable and humane purposes" without the supervision of the military. Connections among labor, punishment, and reform had become more apparent, and moralizing expressions separated and justified the issues in order to mete out proportional and appropriate punishments. ${ }^{49}$

By the second half of the century, some British judicial authorities and philanthropists directed more pointed critiques toward the severity of transportation, particularly for minor offenses. Henry Fielding, the well-known writer and a magistrate in Middlesex, commented prolifically on issues of crime and reform, blaming the maladaptive execution of poor laws and the immorality of the "lowest sort of people." Fielding embraced a patriarchal view of society and contended that "downcharging" formal accusations and limiting pardons had reduced the law's terror. He thought that transportation for petty thievery was so harsh that few judges ordered the punishment. They understood the severity of transportation and were using their discretionary power to select the punishment they considered, or could justify as, morally fitting. Transportation for minor offense needed modification, Fielding argued, since even if offenders preferred to escape their own poverty through colonial servitude, it was more useful for the public to keep those willing to work at home. Accordingly, petty thieves should not wind up in the convict trade; the punishment should fit the crime and thus prevent offenders and their families from feeling the heavy burden of poverty. ${ }^{50}$

Others fretted that communities abused the legal mechanism of transportation by shipping away many who had done little to disrupt the peace. The political economist Joseph Massie explained that people believed that the law provided work for those in need, and thus many regarded the unemployed as rogues or artful beggars. But it was an increase in foreign trade and industry, Massie argued, that had driven significant numbers into poverty, and many of England's poor had turned desperately to thievery or

49. Wilfrid Oldham, Britain's Convicts to the Colonies, ed. W. Hugh Oldham (Erskineville, Australia: Star Printery, 1990), 16. The Board of Trade is noted as the "Lords of Trade" in this text. The latter transitioned into the Lords Commissioners of Trade and Plantations, also known as the Board of Trade, in 1696. See Anthony S. Parent Jr., Foul Means: The Formation of a Slave Society in Virginia, 1660-1740 (Chapel Hill: University of North Carolina Press, 2003), 34n45, and Nancy L. Rhoden, ed., English Atlantics Revisited: Essays Honouring Professor Ian K. Steele (Montreal: McGill-Queen's University Press, 2007), 474-75.

50. Rogers, "Confronting the Crime Wave," 82-85; Henry Fielding, The Complete Works of Henry Fielding, Esq., with an Essay on the Life, Genius and Achievement of the Author, vol. 13, Legal Writings, ed. William Ernest Henley, LL.D. (London: William Heinemann, 1903), 179-80. 
beggary just to stay alive. Consequently, they faced a "Choice of Hanging, Starving, or Transportation." Massie sympathized with the poor and elicited compassion in order to argue for legal changes that distinguished real criminals from those undeserving of punishment, the needy. He found that it was too "easy to convict" thousands of poor and jobless people because their parishes could not or would not care for them. Massie listed various offenses for which he suggested transportation be used only after other punishments had been tried, such as hard labor and the House of Confinement and Corrections, and failed. Both Massie and Fielding displayed a heightened sense of proportionality in disciplinary action and urged for legal changes to modify the convict trade. Their use of moral justifications to articulate their frustrations showed that they wanted people to see them as humble, even sympathetic administrators. ${ }^{51}$

More direct arguments condemned the convict trade for its brutality and inefficiency. The philanthropist Jonas Hanway called for the cessation of the trade, suggesting that imprisonment take its place. He reasoned that the community had lost many able hands through transportation, and some malefactors had avoided the punishment because of "the humanity of judges and juries" that deemed that the laws were too severe. Hanway instead argued for imprisoning offenders and keeping them at terms of labor in order to correct their behavior; he wanted punishment to be proportional to the crime. Because so many had been lost to execution and transportation, he asserted, "We must become ferociously sanguinary, or more determinately humane and consistent." The loss of life and labor fomented concern, and he thought that the law should be changed to show compassion while promoting law-abiding behavior at home and maintaining the labor supply. If Britons could not reduce criminal motives and activities and admit that they were indeed alarmed by levels of violence, the country's vaunted liberties would become a mockery to other nations. He stated, it "tells us, 'you know not what humanity means!'" 52 What is more, the lawyer Henry Dagge argued that convicts were "reduced to slavery in the Plantations," which he considered inefficient. Criminals, Dagge thought, should perform hard labor domestically, and thus benefit their own communities; the courts should banish only the worst criminals to Africa or the South

51. J. (Joseph) Massie, A Plan for the Establishment of Charity-Houses for Exposed or Deserted Women and Girls, and for Penitent Prostitutes . . (London: T. Payne, 1758), 53, 132, emphases in original.

52. Jonas Hanway, The Defects of Police the Cause of Immorality . . (London: J. Dodsley, Brotherton, and Sewell, 1775), 215-16, 224-25, 228, 281-82. 
Sea. "Instead of being excluded from Society," he contended, offenders, "might, after forsaking the habitude of evil, at length be reclaimed." Hard labor at home became an increasingly popular argument, and contemporaries used humanitarian reasoning to push this political agenda..$^{53}$

Although transportation was increasingly criticized, authorities could not agree on a suitable alternative for convicts. Colonists complained about the trade in "Human Serpents," and offenders denounced their punishment as cruel and too severe. But authorities worried that replacing transportation with domestic hard labor might tip the scale of moral disorder at home, so they were reluctant to give it up. In 1773 the London magistrate Sir John Fielding reflected positively on transportation, noting that it provided convicts with "a fresh opportunity of being an useful member of society, thereby answering the great ends of punishment, viz., example, humanity, and reformation." Transportation might not have been the ideal punishment, but he considered it the "most humane and effectual, punishment we have." Fielding's assertions highlight the moral dimension associated with the debate on deporting malefactors and reflect the belief that no other punishment was as efficient or ethical in reforming criminal behavior. The concerns about transportation's severity and proportionality point to a greater investment in understanding the relationship among punishment, morality, labor, and correction and suggest an increasing legitimization of authorities' legal and moral responsibilities to ensure the welfare of convicts and their communities. $^{54}$

The American Revolution officially halted transportation to the United States, and after the outbreak of the war, proposals for more humane punishments, as well as condemnations of cruelty to criminals emerged on both sides of the Atlantic. In 1776 the British Parliament stated that "various Inconveniencies" encumbered transportation; its suggestion that offenders could instead be "reclaimed from their evil Courses" if they received "proper Care and Correction" justified labor at home, and it may have implied that British authorities thought of themselves as more morally upright than Americans. In 1776 Parliament passed a controversial act, the Hulks Act, whereby during the day prisoners performed various labor tasks, including working on the dockyards, and at night they returned to overcrowded and

53. Dagge, Considerations on Criminal Law, 2:183-85.

54. Sir John Fielding, "Sir John Fielding to the Earl of Suffolk," in Calendar of Home Office Papers of the Reign of George III, 1773-1775, ed. Richard Arthur Roberts, 4 vols. (London: HMSO, 1878-1899), 4:10-11; Morgan, "English and American Attitudes towards Convict Transportation, 1718-1775," 422. 
unsanitary anchored ships. In addition to these issues, some worried that this punishment demonstrated monarchical interference with people's liberties, which added to the debate of proper punishment. ${ }^{55}$

English authorities, however, were not prepared to manage the crowded jails, and around the same time as the practice of transportation to the American colonies ended, the movement to create new prisons in England gained traction, in large part because of the philanthropist John Howard's book The State of the Prisons, published in 1777. Howard noted that transportees experienced "many cruelties and impositions" and their "condition was in many respects equally contrary to humanity and good policy." Howard argued that discipline should be administered domestically, which would allow it to be more efficient and uniform rather than a subjective punishment. ${ }^{56}$

Others maintained that transportation was a viable penal option, particularly for capital offenders. In the 1780s Parliament members contemplated West Africa as a potential destination, but opponents of the plan contended that convicts would perish there. Although Parliament passed an act for a penitentiary in 1779 , it did not come to fruition largely because of concerns regarding construction fees, the role of the state in its development, and reintegration of criminals in communities. By 1786 Botany Bay was touted as far enough away to prevent premature returnees, yet as having an environment that would allow convicts to establish new lives there. In January 1788 the first shipment made it to Sydney Cove. Reflecting on the unintentional consequences of transportation in British America, in 1802 Bentham stated, "Unequal in its essence, rendered still more unequal by its accidental concomitants, it was to one man as bad as death, to another a party of pleasure." And yet for years to come, isolation and banishment from Britain's communities would remain central to Parliament's penal policy. ${ }^{57}$

55. Great Britain, The Statutes at Large from the Thirteenth Year of the Reign of King George the Third to the Sixteenth Year of the Reign of King George the Third, Inclusive ... (London: Charles Eyre and William Strahan, and W. Strahan and M. Woodfall, 1776), 12:579, 581; Morgan and Rushton, Eighteenth-Century Criminal Transportation, 155-56; Ekirch, Bound for America, 229-30.

56. Ekirch, Bound for America, 230-31; John Howard, The State of the Prisons in England and Wales, with Preliminary Observations, and an Account of Some Foreign Prisons (Warrington, U.K.: William Eyres, 1777), 75.

57. Ekirch, Bound for America, 230, 236-37. Ekirch (236n1) notes that a small number of merchants ignored U.S. and English prohibitions against taking convicts to America. Philip Harling, "The Trouble with Convicts: From Transportation to Penal Servitude, 1840-67," Journal of British Studies 53 (January 2014): 87; Kercher, "Perish or Prosper," 541-42; Jeremy Bentham, Letter to Lord Pelham, Giving a Com- 
This raises the question of whether shipping convicts to North America really did change British views on transportation and contribute to developing humanitarian sentiment, since convicts continued to be shipped overseas, albeit to a different place. But there was a qualitative difference in transportation to Australia, not just a change in the destination. Though the perspectives on convicts varied over time and with different authorities, a greater effort toward reform as well as control over convict labor accompanied the Australian initiative. By the end of the American convict trade, convicts had increasingly been considered criminals carrying out their punishments, rather than exiles. These notions were expanded in New South Wales. Of course, there were similarities in the locales: convicts in Australia also had a system of passes for leaving their place of work, there were procedures for disciplining offenders, and some earned payment with their "emancipation," as the process of pardoning was termed-which was similar to freedoms some servants in America earned. On the other hand, a more centralized system saw governors in New South Wales, rather than the shippers (as was the case in the American colonies) take charge of new transportees, who could be sent to private masters or to work for the government. Governors also had the power to free convicts through pardons or parole them. To be sure, convicts in Australia could experience great hardships during their punishment. Early journeys to the penal settlement, for example, were marked with illnesses, hunger, and abuse. But although some argued for penal colonies to function as deterrents, governors like Lachlan Macquarie and Richard Bourke and almost all the judges viewed them as rehabilitative. Penal reformers saw moral improvement as a substitute for physical punishment. In the 1770s English magistrates may have been less inclined to use transportation, but overcrowded prisons and the absence of other options gave the system, in Alan Atkinson's words, "a new lease of life" that developed in part because "the moral dimensions of empire were now made to overlap with those of criminal punishment." The experience with North America offered ways to inform the views on how the practice of long-distance convict transportation should work. Emerging notions

parative View of the System of Penal Colonization in New South Wales, and the Home Penitentiary System, . . . (N.p.: n.p., 1802), 23. For an insightful account on the West African experiment with convicts, see Emma Christopher, A Merciless Place: The Fate of Britain's Convicts after the American Revolution (New York: Oxford University Press, 2011). For the reasoning for selecting Botany Bay see, Mollie Gillen, "The Botany Bay Decision, 1786: Convicts, Not Empire," English Historical Review 97, no. 385 (1982): 740-66. 
about cruelty and humane treatment toward fellow human beings swirled in reformists' corners and fueled their hope for a more efficient system. ${ }^{58}$

From an American standpoint, the experience with convicts encouraged legislative change regarding the practice. As the Revolution sparked new political discussions on slavery, it also caused many Americans to reconsider other practices of bound labor. Political leaders in the newly formed United States wasted little time in legally halting convict transportation. In 1788 , for example, a Virginia law noted that "much injury hath been done to the morals, as well as the health, of our fellow-citizens," and the state banned imported criminals beginning the following January. The immoral contagion and disease that convict transportees were thought to have brought became critical reasons for abolishing the trade. After the war, Pennsylvania moralists and legislators embarked on a reformed penal order, instituting a system that sentenced offenders to terms of penal servitude that purportedly would reform criminals and benefit the public. Although these reformers prided themselves on an enlightened disciplinary system, their penal plans faced years of disorder and continued calls for more effective and humane legal revisions. By 1787 early republicans had expanded their commitment to penal servitude with the Continental Congress's Northwest Ordinance, which forbade slavery and involuntary servitude in the Ohio River region, except for "the punishment of crimes." Even though early republicans rejected systems of unfreedom, and many, like Benjamin Franklin, condemned the colonial convict trade as immoral, lawmakers nevertheless provided for the expansion of penal servitude into the West with this landmark law. The story of humanitarian sentiment evoked by American penal servitude, like the British initiation of convict transportation to Australia, did not move inexorably and in a unilinear fashion toward bettering human welfare. Americans banned the foreign convict trade, yet penal labor emerged as a pivotal part of the new nation's penological plan. Nevertheless, early Americans' identifications of unnecessarily severe suffering and efforts for rehabilitation fueled the later reform movements and galvanized early

58. Kercher, "Perish or Prosper," 541-42, 567-68, 581-84. Kercher states, "Slavery, convict labor, and indentured labor were all different, but in Virginia and Maryland they had much in common as well: people, or their labor, could be property and with that word came a powerful body of rights." He deemed this property right as key to understanding the discourse on convict labor in New South Wales (582). Atkinson, "The Free-Born Englishman Transported," 92, 109-15; Gillen, "The Botany Bay Decision,” 765-66; Christopher, “'The Slave Trade Is Merciful Compared to [This]," 118-19, 123-24. 
republicans to embark on a campaign for more humane legal and cultural changes regarding punishments in the new republic. ${ }^{59}$

\section{CONCLUSION}

Banishment and penal servitude played an important role in shaping humanitarian sensibilities in the eighteenth century. Britons and Americans used transportation and servitude as instructional devices to evoke sympathy for unfree laborers, to critique cruelty in colonial laws on labor, and to advocate for new humane labor practices in arguments that prefigured nineteenth-century debates on humanity and unfreedom. Convict transportation shaped, and was shaped by, economic agendas and political discourse, but it was also a significant rhetorical tool that linked emerging ideas of sensibility with moral accountability. Evoking ideas of compassion, sympathy, dehumanization, and humanity helped structure moral vocabularies that advocates used to support their agendas while exposing links with chattel slavery that perhaps provoked some to consider the conditions of African bondage more closely. Convict servitude, however, remained distinct from the brutal and perpetual experience African enslaved people suffered.

Transportation's reputation for severity, as highlighted by the thief Edward Williams, encouraged contemporaries to weigh in with their concerns, as they argued about the usefulness of the practice and proposed measures to support or abolish the trade in coerced labor. Though some commentators noted the justness or severity in the punishment, many were

59. Fogleman, "From Slaves, Convicts, and Servants to Free Passengers"; Winfield Scott Craig, "Bonds of Empire: The Politics of Penal Colonies in the Founding of America and Australia" (Ph.D. diss, Florida State University, 2014); Rebecca M. McLennan, The Crisis of Imprisonment: Protest, Politics, and the Making of the American Penal State, 1776-1941 (Cambridge: Cambridge University Press, 2008), 23, 25-27, 30-34; William W. Hening, ed., The Statutes at Large: Being a Collection of All the Laws of Virginia from the First Session of the Legislature in the Year 1619 (New York: R. \& W. \& G. Bartow, 1819-23), 12:668-69; Northwest Ordinance: An Ordinance for the Government of the Territory of the United States Northwest of the River Ohio, July 13, 1787, Avalon Project at Yale Law School, http://avalon.law yale.edu; Leonard W. Levy, Jefferson E Civil Liberties: The Darker Side (Cambridge: Belknap Press of Harvard University Press, 1963), 33-34. The idea of legal exile and coercion has a long history. For example, the Magna Carta states, "No free man shall be seized or imprisoned, or stripped of his rights or possessions, or outlawed or exiled, or deprived of his standing in any other way, nor will we proceed with force against him, or send others to do so, except by the lawful judgement of his equals or by the law of the land." "The Text of Magna Carta," Fordham University, https://sourcebooks.fordham.edu/source/magnacarta.asp. 
more concerned with the maliciousness of administering suffering to offenders, which engendered sentiments on moral responsibility and unfreedom. As Lynn Festa points out, humanitarian sensibility is just one component of the history of humanitarianism, which in turn is but one feature of the history of the long eighteenth century. Yet these humanitarian issues were important to the foundation of human rights culture, revealing changes in moral thinking and practices that allowed people to imagine personal and collective reform. The debates over institutional banishment and servitude show where notions of moral universality and inclusion were expanding and contracting. They provided key venues for Britons and Americans to express their beliefs, sympathies, and moral responsibilities, while fostering the formation of a new culture of sensibility in the AngloAmerican world. ${ }^{60}$

60. Festa, "Humanity without Feathers," 19; Green, "Humanitarianism in Nineteenth-Century Context," 1157-58. 